\title{
Review
}

\section{Feeding and Swallowing Disorders in Pediatric Neuromuscular Diseases: An Overview}

\author{
Lenie van den Engel-Hoek ${ }^{\mathrm{a}, *}$, Imelda J.M. de Groot ${ }^{\mathrm{a}}$, Bert J.M. de Swart ${ }^{\mathrm{a}}$ and Corrie E. Erasmus ${ }^{\mathrm{b}}$ \\ ${ }^{a}$ Donders Centre for Neuroscience, Department of Rehabilitation, Radboud University Medical Center, \\ Nijmegen, The Netherlands \\ ${ }^{\mathrm{b}}$ Donders Centre for Neuroscience, Department of Neurology, Radboud University Medical Center, \\ Nijmegen, The Netherlands
}

\begin{abstract}
Feeding and swallowing problems in infants and children have a great impact on health and wellbeing. The aim of this study was to provide an overview of recognized feeding and swallowing problems in different groups of children with neuromuscular diseases, based on relevant literature and expert opinion, and to propose recommendations for the assessment and treatment of these problems. Almost all pediatric neuromuscular diseases are accompanied by feeding and swallowing problems during the different phases of deglutition, problems that give rise to a wide variety of signs and symptoms, which emphasizes the importance of a comprehensive feeding and swallowing assessment by a speech and language therapist.
\end{abstract}

Keywords: Pediatric neuromuscular diseases, swallowing phases, feeding problems, dysphagia

\section{INTRODUCTION}

Children with neurologic disabilities frequently have problems with feeding and swallowing. In 2007, the American Speech-Language-Hearing Association adopted "feeding and swallowing disorders" as a more inclusive phrase for disorders in the development of eating and drinking skills and dysphagia, disorders that are common in various pediatric populations. Feeding disorders are defined as problems with eating activities, such as sucking during breastfeeding or bottle-feeding, eating with a spoon, chewing, or drinking from a cup. Swallowing disorders, or dysphagia, are defined as abnormalities in one of the four phases of the normal swallowing mechanism, namely, the oral preparatory, oral transport, pharyngeal, and esophageal phases [1].

*Correspondence to: Lenie van den Engel-Hoek, PhD, Radboud University Medical Center, Nijmegen, Geert Grooteplein 10, Internal post 818, 6525 GA Nijmegen, The Netherlands. Tel.: +31 24 3615187; E-mail: Lenie.vandenEngel-Hoek@radboudumc.nl.
Feeding and swallowing disorders in children with neurodevelopmental disabilities have a great impact on the health and wellbeing of these children and their families. Feeding disorders, choking, and aspiration have been described in children with neuromuscular diseases (NMDs) and in children with cerebral palsy $[2,3]$, but the underlying causes and swallowing patterns are different in NMDs and cerebral palsy [4]. In general, children with cerebral palsy are at risk of aspirating thin fluids, whereas children with NMDs lack the muscle strength required to swallow solid food properly $[4,5]$. Muscle weakness is a common feature of childhood NMDs, although the factors contributing to, and the pattern of, muscle weakness vary in the different types of NMD.

The aim of this study was to provide an overview of the known feeding and swallowing problems of different groups of children with NMDs and to propose recommendations for the assessment and treatment of these problems. 


\section{NEUROMUSCULAR DISEASES IN CHILDREN}

NMDs are acquired or inherited (genetic) conditions affecting the neuromuscular system, with hypotonia due to muscle weakness being the predominant characteristic symptom. NMDs are broadly subdivided into muscular dystrophies, myopathies, and neuropathies. Some common NMDs seen in children are listed in Table 1.

\section{NORMAL DEVELOPMENT OF FEEDING SKILLS AND SWALLOWING}

Initially, neonates suckle from the breast (or bottle), but after about 3 months brainstem reflexes, such as the sucking reflex, disappear and by about 6 months infants start eating foods of different consistencies. The oral anatomy changes as a result of the growth of the oral cavity and the descent of laryngeal structures. Between 6 and 12 months, infants learn to chew and swallow pureed or solid food [8], which requires greater strength of the oral muscles. The complete swallowing mechanism develops thereafter, with the adult swallowing pattern being reached in puberty, after the pharynx has attained its adult length.

\section{ASSESSMENT OF PEDIATRIC FEEDING AND SWALLOWING DISORDERS}

A feeding disorder refers to problems in the development of feeding skills, such as sucking from breast

Table 1

Neuromuscular diseases in infancy and childhood, adapted from Dubowitz (1996), Yang (2010), and the gene table of the World Muscle society, which is regularly updated (www.musclegenetable.fr/) $[6,7]$

\begin{tabular}{|c|c|c|c|c|}
\hline Anatomical area & Disorder & Example (children) & Age at presentation & $\begin{array}{l}\text { Progressive or } \\
\text { non-progressive }\end{array}$ \\
\hline \multirow[t]{2}{*}{ Anterior horn cell } & $\begin{array}{l}\text { Spinal muscular atrophy } \\
\text { (SMA) (type I-IV) }\end{array}$ & SMA type I, II and III & Type I <6 m & Progressive \\
\hline & & & $\begin{array}{l}\text { Type II 6-18 m } \\
\text { Type III >18 m }\end{array}$ & \\
\hline \multirow[t]{3}{*}{ Nerve fiber } & $\begin{array}{l}\text { Hereditary motor and sensory } \\
\text { neuropathies (HMSN) } \\
\text { (type } 1-4)\end{array}$ & $\begin{array}{l}\text { HMSN type } 1 \mathrm{~A} \text { en } 2 \mathrm{~A} \\
\text { (Charcot-Marie-Tooth } \\
\text { disease) }\end{array}$ & Child - adult & $\begin{array}{l}\text { Slow progression over } \\
\text { decades }\end{array}$ \\
\hline & $\begin{array}{l}\text { Hereditary sensory and } \\
\text { autonomic neuropathies } \\
\text { (HSAN) }\end{array}$ & $\begin{array}{l}\text { Congenital sensory } \\
\text { neuropathy, HSAN type II; }\end{array}$ & Infancy & Slow change over time \\
\hline & & Riley-Day, HSAN type III & Birth & $\begin{array}{l}\text { Progressive, usually fatal: } \\
\text { death in } 50 \%<30-40 \text { years }\end{array}$ \\
\hline \multirow[t]{3}{*}{$\begin{array}{l}\text { Neuromuscular } \\
\text { junction }\end{array}$} & $\begin{array}{l}\text { Pediatric myasthenic } \\
\text { syndrome }\end{array}$ & $\begin{array}{l}\text { Transient neonatal } \\
\text { myasthenia gravis }\end{array}$ & Infancy & Remission in $1-6$ weeks \\
\hline & & $\begin{array}{l}\text { Congenital myasthenic } \\
\text { syndrome }\end{array}$ & Birth - 2 y & $\begin{array}{l}\text { Usual: slowly progressive or } \\
\text { fixed weakness into } \\
\text { adulthood }\end{array}$ \\
\hline & & Juvenile myasthenia gravis & Infancy - childhood & Improve over years \\
\hline \multirow[t]{9}{*}{ Muscle } & Muscular dystrophy & $\begin{array}{l}\text { Duchenne muscular } \\
\text { dystrophy }\end{array}$ & $2-5 y$ & Progressive \\
\hline & Myotonic dystrophy type 1 & $\begin{array}{l}\text { Congenital myotonic } \\
\text { dystrophy }\end{array}$ & Birth & $\begin{array}{l}\text { Slowly progressive, neonatal } \\
\text { distress }(50 \%)\end{array}$ \\
\hline & $\begin{array}{l}\text { Congenital myopathy } \\
\text { Nemaline (Rod) myopathy }\end{array}$ & Childhood onset & Infancy & Slowly progressive \\
\hline & & Multicore myopathy & Birth $(90 \%)$ & Progressive \\
\hline & & Centronuclear myopathy & $\begin{array}{l}\text { Birth to Childhood } \\
\text { Birth }\end{array}$ & $\begin{array}{l}\text { Non- or slowly progressive } \\
\text { Progressive, early death } \\
\text { Slowly or non-progressive }\end{array}$ \\
\hline & & $\begin{array}{l}\text { Congenital fiber type } \\
\text { disproportion }\end{array}$ & Infancy-childhood & Progressive \\
\hline & Metabolic myopathies & Mitochondrial myopathy & Infancy & Progressive \\
\hline & & $\begin{array}{l}\text { Glycogen storage disease } \\
\text { (infantile Pompe disease) }\end{array}$ & Infancy & $\begin{array}{l}\text { Incomplete recovery: } \\
\text { common. }\end{array}$ \\
\hline & Polymyositis/Dermatomyositis & Juvenile dermatomyositis & Childhood & $\begin{array}{l}\text { Relapses (polycyclic): } \\
\text { common } \\
\text { Chronic course requiring } \\
\text { medication }>3 \text { years: } 30 \% \\
\text { to } 60 \%\end{array}$ \\
\hline
\end{tabular}


Table 2

Swallowing phase and related problems, based on Arvedson (2008) [9]

\begin{tabular}{ll}
\hline Swallowing phase & Probable related problems \\
\hline Oral preparatory phase & $\begin{array}{l}\text { Inadequate lip closure and disturbed tongue movements result in sucking problems in the neonatal period, loss of } \\
\text { food from the mouth and mastication problems } \\
\text { Oral transport phase } \\
\text { Pharyngeal phase }\end{array}$ \\
$\begin{array}{l}\text { Problems with bolus formation and prolonged oral transport due to reduced tongue strength } \\
\text { Poling in the pharynx due to reduced tongue elevation, poor intraoral bolus control, and poor posterior tongue } \\
\text { propulsion causing a delay in the initiation of pharyngeal swallow } \\
\text { Nasal regurgitation due to incoordination of pharyngeal contractions or insufficient closure of the nasopharyngeal } \\
\text { area. } \\
\text { Penetration of food underneath the epiglottis or (silent) aspiration due to timing and coordination deficits. } \\
\text { Residue after swallow in the valleculae and piriform sinuses caused by reduced activity of the submental muscle } \\
\text { group, which results in decreased anterosuperior movement of the hyoid, reduced tongue base retraction, or } \\
\text { reduced pharyngeal contractions. } \\
\text { Residue above the upper esophageal sphincter due to limited opening of the sphincter. } \\
\text { Residue or pooling in the proximal esophagus due to motility problems or gastroesophageal reflux. }\end{array}$ \\
Esophageal phase
\end{tabular}

or bottle, eating from a spoon, chewing, or drinking from a cup, while a swallowing disorder, or dysphagia, refers to problems in one or more phases of the swallowing process (Table 2) [9].

In infants and children with feeding and swallowing disorders, a comprehensive swallowing assessment is necessary in order to provide adequate management and recommendations for efficient and safe feeding. In accordance with the International Classification of Functioning, Disability and Health (ICF), the assessment includes information on mealtime environment (participation), activities of the child during mealtimes (activities), and motor skills, neuromotor development, and neuromuscular conditions (body function and structures) $[9,10]$. It includes making an inventory of feeding and swallowing problems, observing eating and drinking of different consistencies, and assessing neuromotor development and oral motor skills. If there is concern about safe swallowing, a video fluoroscopic swallow study (VFSS) or a flexible endoscopic evaluation of swallowing (FEES) should be performed [11].

Swallowing in children and adults is different, in the sense that mouth and digestive anatomy is different in children and adults, and so, in general, is the consistency of food eaten and hence the consistency of the bolus swallowed [12]. Feeding skills are developed during infancy and childhood, and the changing oral and pharyngeal anatomy during this time necessitates careful assessment during the consecutive stages of infancy and childhood.

\section{METHODS}

Members of the Children's Swallowing Team (LE and $\mathrm{CE}$ ) of the Radboud University Medical Centre (the Netherlands) reviewed the literature (Pubmed and Web of Science) using the search terms 'feeding problems AND infants/children', 'swallowing problems AND infants/children', 'dysphagia AND infants/children', all in combination with various neuromuscular diseases (Table 3). Only English-language articles were included, published from 1985 until 2014. The first search identified 75 articles, of which 62 were included (Table 3). Articles were included if they provided information on the oral preparatory, oral transport, pharyngeal, and/or esophageal phases of swallowing.

\section{RESULTS: FEEDING AND SWALLOWING PROBLEMS IN CHILDREN WITH NMD}

The various problems associated with the four phases of swallowing seen in children with NMDs are presented in Table 3. In many cases, problems occur in more than one phase. The oral (preparatory) phase is often complicated by structural impairments, such as limited mouth opening, inability to close the mouth due to malocclusions, or structural abnormalities of the tongue.

\section{DISCUSSION}

The common element in all NMDs is muscle weakness, which influences motor abilities and oral motor activities, with the pattern of eating or swallowing problems being influenced by the specific muscle groups affected by the NMD. Moreover, a wide variety of signs and symptoms are caused by aspecific (not disease) dependent variables including (a) the onset of signs and symptoms, (b) the phase of dysfunctional swallowing, (c) disease progression, and (d) bulbar muscle involvement. 
Table 3

Feeding and swallowing problems in pediatric neuromuscular diseases

\begin{tabular}{|c|c|c|c|c|}
\hline $\begin{array}{l}\text { Neuromuscular disorder } \\
\text { and general signs }\end{array}$ & $\begin{array}{l}\text { Problems in the oral } \\
\text { preparatory phase }^{\mathrm{a}}\end{array}$ & $\begin{array}{l}\text { Problems in the oral } \\
\text { (transport) phase }{ }^{\mathrm{b}}\end{array}$ & $\begin{array}{l}\text { Problems in the } \\
\text { pharyngeal phase }^{c}\end{array}$ & $\begin{array}{l}\text { Problems in (upper) } \\
\text { esophageal phase }^{\mathrm{d}}\end{array}$ \\
\hline \multicolumn{5}{|c|}{ Spinal Muscular Atrophy (SMA) [13] } \\
\hline $\begin{array}{l}\text { SMA I } \\
\text { Most severe with early } \\
\text { morbidity and mortality } \\
{[14]}\end{array}$ & $\begin{array}{l}\text { Disturbed and weak } \\
\text { sucking [14] }\end{array}$ & $\begin{array}{l}\text { Problems with handling } \\
\text { oral secretions [13] }\end{array}$ & $\begin{array}{l}\text { Decreased airway } \\
\text { protection in } \\
\text { combination with weak } \\
\text { swallowing results in } \\
\text { increased risk in } \\
\text { aspiration pneumonia } \\
\text { [13] }\end{array}$ & $\begin{array}{l}\text { High incidence of } \\
\text { gastroesophageal reflux } \\
\text { (GER) [15] }\end{array}$ \\
\hline $\begin{array}{l}\text { SMA II } \\
\text { Characterized by the } \\
\text { ability to maintain a } \\
\text { sitting position } \\
\text { unsupported [14] }\end{array}$ & $\begin{array}{l}\text { Mastication problems in } \\
\text { combination with } \\
\text { limited mouth opening } \\
{[16-18]}\end{array}$ & $\begin{array}{l}\text { Piecemeal deglutition } \\
\text { (need for multiple } \\
\text { swallows to clear the } \\
\text { oral cavity), more often } \\
\text { with solid food than } \\
\text { thin liquid [5] }\end{array}$ & $\begin{array}{l}\text { Post-swallow residue in } \\
\text { the valleculae and } \\
\text { above the upper } \\
\text { esophageal sphincter, } \\
\text { more often with solid } \\
\text { food than thin liquid, } \\
\text { and posture dependent } \\
\text { [5] }\end{array}$ & $\begin{array}{l}\text { Post-swallow residue } \\
\text { after swallow above the } \\
\text { upper esophageal } \\
\text { sphincter (UES) [5]; } \\
\text { symptoms of GER [19, } \\
\text { 20] }\end{array}$ \\
\hline $\begin{array}{l}\text { SMA III } \\
\text { Later time of onset; } \\
\text { patients are usually able } \\
\text { to walk [14] }\end{array}$ & $\begin{array}{l}\text { Mastication problems in } \\
20 \% \text { of the patients [ } 21 \text {, } \\
22]\end{array}$ & Not reported & $\begin{array}{l}\text { Choking, more often with } \\
\text { solid food than thin } \\
\text { liquid; poor head } \\
\text { control is related with } \\
\text { feeding and swallowing } \\
\text { problems [22] }\end{array}$ & Not reported \\
\hline \multicolumn{5}{|c|}{ Hereditary motor/sensory and autonomic neuropathies (HMSN/HSAN) [23] } \\
\hline HMSN type 1 or 2 [23] & Not reported & Not reported & $\begin{array}{l}\text { In late onset (from } 13 \\
\text { years): occasionally } \\
\text { dysphagia with } \\
\text { aspiration pneumonia } \\
\text { [24] }\end{array}$ & $\begin{array}{l}\text { Occasionally vomiting } \\
\text { due to achalasia [25] }\end{array}$ \\
\hline $\begin{array}{l}\text { Congenital sensory } \\
\text { neuropathy, HSAN type } \\
\text { II [26] }\end{array}$ & Poor sucking [26] & $\begin{array}{l}\text { Feeding problems, not } \\
\text { specified [27] }\end{array}$ & $\begin{array}{l}\text { Feedings problems with } \\
\text { apnea due to } \\
\text { incoordination in the } \\
\text { neonatal period [27] } \\
\text { Oropharyngeal } \\
\text { dysphagia, more often } \\
\text { with liquid than solids } \\
\text { and nasal regurgitation } \\
\text { [26] }\end{array}$ & $\begin{array}{l}\text { Vomiting due to GER and } \\
\text { delayed gastric } \\
\text { emptying [26] }\end{array}$ \\
\hline $\begin{array}{l}\text { Riley-Day, HSAN type } \\
\text { III: sensory dysfunction } \\
\text { and progressive feeding } \\
\text { disorders from birth } \\
{[26]} \\
\end{array}$ & $\begin{array}{l}\text { Poor oral coordination } \\
\text { and hypotonia [27] }\end{array}$ & $\begin{array}{l}\text { Poor oral coordination } \\
\text { [27] }\end{array}$ & $\begin{array}{l}\text { Misdirection, especially } \\
\text { of liquids [27] with } \\
\text { high risk for aspiration }\end{array}$ & $\begin{array}{l}\text { High frequency of GER, } \\
\text { which can result in } \\
\text { chronic lung disease in } \\
\text { combination with } \\
\text { aspiration [26] }\end{array}$ \\
\hline \multicolumn{5}{|c|}{ Pediatric myasthenic syndromes $[28,29]$} \\
\hline $\begin{array}{l}\text { Congenital myasthenic } \\
\text { syndromes, } \\
\text { non-progressive } \\
\text { fluctuating muscle } \\
\text { weakness from birth } \\
\text { [30] }\end{array}$ & $\begin{array}{l}\text { Poor sucking due to } \\
\text { bulbar weakness [31, } \\
\text { 32] }\end{array}$ & $\begin{array}{l}\text { Poor oral transport due to } \\
\text { bulbar weakness [32] }\end{array}$ & $\begin{array}{l}\text { Nasal regurgitation, due } \\
\text { to palatal weakness } \\
\text { [28], choking due to } \\
\text { respiratory problems } \\
\text { with apneic episodes } \\
{[30,32]}\end{array}$ & Not reported \\
\hline $\begin{array}{l}\text { Transient myasthenia } \\
\text { gravis, generalized } \\
\text { muscle weakness with } \\
\text { resolution typically } \\
\text { within a few weeks [29, } \\
\text { 33] }\end{array}$ & $\begin{array}{l}\text { Facial weakness with } \\
\text { sucking difficulties [33] }\end{array}$ & $\begin{array}{l}\text { Poor oral transport due to } \\
\text { weakness [33] }\end{array}$ & $\begin{array}{l}\text { Swallowing difficulties in } \\
\text { combination with } \\
\text { respiratory distress [29, } \\
\text { 33] }\end{array}$ & Not reported \\
\hline
\end{tabular}


Table 3

(Continued)

\begin{tabular}{|c|c|c|c|c|}
\hline $\begin{array}{l}\text { Neuromuscular disorder } \\
\text { and general signs }\end{array}$ & $\begin{array}{l}\text { Problems in the oral } \\
\text { preparatory phase }^{\mathrm{a}}\end{array}$ & $\begin{array}{l}\text { Problems in the oral } \\
\text { (transport) phase }\end{array}$ & $\begin{array}{l}\text { Problems in the } \\
\text { pharyngeal phase }^{\mathrm{c}}\end{array}$ & $\begin{array}{c}\text { Problems in (upper) } \\
\text { esophageal phase }^{\mathrm{d}}\end{array}$ \\
\hline $\begin{array}{l}\text { Juvenile myasthenia } \\
\text { gravis, fatigable ptosis, } \\
\text { dysarthria, and } \\
\text { extremity weakness } \\
{[28]}\end{array}$ & $\begin{array}{l}\text { Poor sucking or drinking } \\
\text { from a straw, } \\
\text { mastication problems } \\
\text { due to affected oral and } \\
\text { facial muscles }[29,34]\end{array}$ & $\begin{array}{r}\text { Difficulties swallowing } \\
\text { water and saliva [34] }\end{array}$ & $\begin{array}{l}\text { Nasal regurgitation, due } \\
\text { to palatal weakness } \\
\text { [28], choking on solid } \\
\text { food due to affected } \\
\text { pharyngeal muscles } \\
\text { [35] }\end{array}$ & Not reported \\
\hline
\end{tabular}

Muscular dystrophy [36]

Duchenne muscular dystrophy, progressive muscle weakness due dystrophic muscle degeneration, loss of ambulation between 9 and 13 years [37]
Mastication problems due Piecemeal deglutition to masseter muscle weakness and malocclusions including limited mouth opening [38], starting at about 8 years of age $[39,40]$ more often with solid food than thin liquid, due to dystrophic tongue muscles in the early and late non-ambulatory stage [41]
Pharyngeal post-swallow residue [42], most frequently with thick liquid and solid food in the early and late non-ambulatory stage, due to dystrophic submental muscles, risk for indirect aspiration [41]

\begin{tabular}{|c|c|c|c|c|}
\hline \multicolumn{5}{|c|}{ Myotonic dystrophy type 1 [44] } \\
\hline $\begin{array}{l}\text { Congenital myotonic } \\
\text { dystrophy, severe } \\
\text { generalized weakness } \\
\text { and respiratory distress } \\
\text { in the neonatal period } \\
\text { [45]; polyhydramnios } \\
\text { (as sign of poor fetal } \\
\text { swallowing) [44] }\end{array}$ & $\begin{array}{l}\text { Weak sucking due to } \\
\text { facial weakness and a } \\
\text { tented upper lip [46]; } \\
\text { hypomimia, open } \\
\text { mouth and temporal } \\
\text { muscle atrophy hamper } \\
\text { spoon feeding and } \\
\text { chewing [47]; drooling } \\
\text { [44] }\end{array}$ & $\begin{array}{l}\text { Open mouth and } \\
\text { weakness of the tongue } \\
\text { may cause problems in } \\
\text { transporting food to the } \\
\text { pharyngeal area with } \\
\text { oral residue [47] }\end{array}$ & $\begin{array}{l}\text { Severe coordination } \\
\text { problems with sucking, } \\
\text { swallowing, and } \\
\text { breathing [48] }\end{array}$ & $\begin{array}{l}\text { Occasionally GER } \\
\text { problems and } \\
\text { gastrointestinal } \\
\text { dysmotility [49] }\end{array}$ \\
\hline $\begin{array}{l}\text { Childhood-onset } \\
\text { myotonic dystrophy, } \\
\text { usually a normal } \\
\text { neonatal period, only } \\
\text { transitory feeding } \\
\text { problems [48] }\end{array}$ & $\begin{array}{l}\text { Facial and oral weakness } \\
\text { with problems getting } \\
\text { food from the spoon } \\
\text { and with mastication; } \\
\text { food and liquid leak out } \\
\text { corners of the mouth } \\
\text { [47] }\end{array}$ & $\begin{array}{l}\text { Food gets stuck in gums } \\
\text { and it takes long to } \\
\text { swallow food, due to } \\
\text { tongue weakness [47] }\end{array}$ & $\begin{array}{l}\text { Occasional nasal } \\
\text { regurgitation, choking } \\
\text { on solid food, coughing } \\
\text { when swallowing } \\
\text { liquids [47] }\end{array}$ & Not reported \\
\hline \multicolumn{5}{|l|}{ Congenital myopathies [50] } \\
\hline $\begin{array}{l}\text { Nemaline myopathy, } \\
\text { muscle weakness most } \\
\text { severe in face, neck and } \\
\text { proximal limbs [51], } \\
\text { occasionally } \\
\text { polyhydramnios [52] }\end{array}$ & $\begin{array}{l}\text { Tented upper lip, high } \\
\text { arched palate and } \\
\text { retrognathia cause } \\
\text { sucking problems; open } \\
\text { bite malocclusion with } \\
\text { weak chewing; drooling } \\
\text { [51] }\end{array}$ & $\begin{array}{l}\text { Bolus formation problems } \\
\text { (liquid and solid) [52] }\end{array}$ & $\begin{array}{l}\text { Nasal regurgitation and } \\
\text { residue after swallow } \\
\text { due to poor pharyngeal } \\
\text { propulsion [53]; } \\
\text { occasionally } \\
\text { penetration and } \\
\text { aspiration [52]; } \\
\text { aspiration of oral } \\
\text { secretions [54] }\end{array}$ & $\begin{array}{l}\text { Occasionally esophageal } \\
\text { dysmotility [52] and } \\
\text { GER [54] }\end{array}$ \\
\hline $\begin{array}{l}\text { Core myopathy } \\
\text { (including central core } \\
\text { and multiminicore } \\
\text { disease), static or only } \\
\text { slowly progressive } \\
\text { weakness with bulbar } \\
\text { and respiratory } \\
\text { involvement }[55,56]\end{array}$ & $\begin{array}{l}\text { Facial weakness with a } \\
\text { high arched palate } \\
\text { causes neonatal sucking } \\
\text { problems, occasionally } \\
\text { drooling [56] }\end{array}$ & $\begin{array}{l}\text { Dysphagia (not specified) } \\
\text { [57] }\end{array}$ & $\begin{array}{l}\text { Dysphagia (not specified) } \\
\text { [57], with respiratory } \\
\text { distress, occasionally } \\
\text { aspiration [58] }\end{array}$ & Occasionally GER [58] \\
\hline
\end{tabular}


Table 3

(Continued)

\begin{tabular}{|c|c|c|c|c|}
\hline $\begin{array}{l}\text { Neuromuscular disorder } \\
\text { and general signs }\end{array}$ & $\begin{array}{l}\text { Problems in the oral } \\
\text { preparatory phase }^{\mathrm{a}}\end{array}$ & $\begin{array}{l}\text { Problems in the oral } \\
\text { (transport) phase }{ }^{\mathrm{b}}\end{array}$ & $\begin{array}{l}\text { Problems in the } \\
\text { pharyngeal phase }{ }^{c}\end{array}$ & $\begin{array}{r}\text { Problems in (upper) } \\
\text { esophageal phase }^{\mathrm{d}} \\
\end{array}$ \\
\hline $\begin{array}{l}\text { Centronuclear myopathy, } \\
\text { occasionally with } \\
\text { bulbar involvement [58] }\end{array}$ & $\begin{array}{l}\text { Bulbar weakness with } \\
\text { insufficient sucking and } \\
\text { drooling }[50,59]\end{array}$ & $\begin{array}{l}\text { Dysphagia (not specified) } \\
{[50,57]}\end{array}$ & $\begin{array}{l}\text { Dysphagia (not specified) } \\
\text { with respiratory distress } \\
\text { [51] }\end{array}$ & Not reported \\
\hline $\begin{array}{l}\text { Congenital fiber type } \\
\text { disproportion, can } \\
\text { present at birth with } \\
\text { weakness and } \\
\text { hypotonia; static or } \\
\text { improving course [60] }\end{array}$ & $\begin{array}{l}\text { Facial weakness with } \\
\text { mild to moderate } \\
\text { feeding difficulties [61] }\end{array}$ & $\begin{array}{l}\text { Feeding difficulties (not } \\
\text { specified) [61] }\end{array}$ & $\begin{array}{c}\text { Bulbar weakness, } \\
\text { dysphagia (not } \\
\text { specified) [61] }\end{array}$ & Not reported \\
\hline
\end{tabular}

\begin{tabular}{|c|c|c|c|c|}
\hline \multicolumn{5}{|l|}{ Metabolic myopathies [62] } \\
\hline $\begin{array}{l}\text { Mitochondrial myopathy, } \\
\text { varying degree of } \\
\text { muscle symptoms, } \\
\text { decreased endurance or } \\
\text { weakness, due to defect } \\
\text { in electron transport } \\
\text { chain function [63] }\end{array}$ & $\begin{array}{l}\text { Mastication problems due } \\
\text { to decreased endurance; } \\
\text { In Leigh syndrome: } \\
\text { sucking problems in the } \\
\text { neonatal period [64] }\end{array}$ & Not reported & $\begin{array}{l}\text { Leigh: dysphagia with } \\
\text { respiratory distress and } \\
\text { aspiration, probably } \\
\text { due to brainstem } \\
\text { involvement [64] }\end{array}$ & $\begin{array}{l}\text { Gastrointestinal } \\
\text { dysfunction }[64,65]\end{array}$ \\
\hline $\begin{array}{l}\text { Pompe disease, rare } \\
\text { lysosomal storage } \\
\text { disorder which present } \\
\text { in the first months of } \\
\text { life with progressive } \\
\text { muscle weakness [66] }\end{array}$ & $\begin{array}{l}\text { Sucking and mastication } \\
\text { problems due oral and } \\
\text { facial weakness with } \\
\text { sunken cheeks and } \\
\text { dropped lower lip [67], } \\
\text { problems with saliva } \\
\text { control [68] }\end{array}$ & $\begin{array}{c}\text { Transport problems due to } \\
\text { weakness of the tongue } \\
\text { with oral residue [68] }\end{array}$ & $\begin{array}{l}\text { Weak swallowing with } \\
\text { nasal regurgitation; } \\
\text { post-swallow residue } \\
\text { and saliva in valleculae } \\
\text { and on pharyngeal wall; } \\
\text { occasionally } \\
\text { penetration of food } \\
\text { [67], occasionally } \\
\text { delayed initiation of } \\
\text { swallowing [66] }\end{array}$ & $\begin{array}{l}\text { Post-swallow residue } \\
\text { above the upper } \\
\text { esophageal sphincter } \\
\text { [66]; occasionally GER } \\
\text { [68] }\end{array}$ \\
\hline \multicolumn{5}{|c|}{ Polymyositis / dermatomyositis [69] } \\
\hline $\begin{array}{l}\text { Juvenile dermatomyositis, } \\
\text { rare inflammatory } \\
\text { multi-system disease, } \\
\text { that primarily involves } \\
\text { the skin and muscles, } \\
\text { but may affect other } \\
\text { organs [70] }\end{array}$ & $\begin{array}{l}\text { Complains about } \\
\text { weakness and pain in } \\
\text { mastication muscles } \\
\text { [71] }\end{array}$ & $\begin{array}{l}\text { Possibly piecemeal } \\
\text { deglutition due to } \\
\text { reduced tongue force }\end{array}$ & $\begin{array}{l}\text { Nasal regurgitation, } \\
\text { delayed pharyngeal } \\
\text { swallow, post-swallow } \\
\text { residue and aspiration } \\
\text { of liquids [71] }\end{array}$ & $\begin{array}{l}\text { Occasionally } \\
\text { gastrointestinal } \\
\text { involvement [72] }\end{array}$ \\
\hline
\end{tabular}

${ }^{a}$ Sucking, holding liquids in the oral cavity, mastication, and preparing the bolus for swallowing; ${ }^{\mathrm{b}}$ Anterior to posterior oral transport of the bolus by the tongue for passage to the pharynx; ${ }^{\mathrm{c}}$ Transport of the bolus through the pharyngeal area with closure of the nasal area and larynx; ${ }^{\mathrm{d}}$ Passage of the bolus through the cricopharyngeal muscle into the esophagus and transport to the stomac.

\section{(a) Onset of signs and symptoms}

Fetal dysphagia occurs in relation to polyhydramnios in some NMDs, which is important to observe and relate to possible swallowing problems. Feeding problems may present at birth, with a neonatal onset and are often related to weak sucking. In most NMDs, with the exception of spinal muscular atrophy, the triggering and timing of swallowing in the bulbar region is normal [13], so that dysphagia is mainly related to weakness of the oral muscles rather than to incoordination of sucking, swallowing, and breathing. Coughing during feeding in the neonatal period in infants with an NMD is mainly related to pharyngeal residue after swallowing. This emphasizes the need for a thorough feeding and swallowing assessment, in order to make the right decisions regarding food adaptation. In neonates with weak sucking, thickened liquids require stronger suction and could make problems with pharyngeal residue worse [73]. Tailor-made interventions with a focus on the safety of swallowing and making use of soft nipples, diminished suck-swallow sequences, and limited feeding time may be necessary $[53,74]$. If sucking and swallowing are too weak, unsafe, or impossible, a feeding tube is needed to prevent aspiration and to provide adequate nutritional intake. Chewing difficulties can be a later complication, leading to prolonged mealtimes, choking, or 
asphyxiation, and a low food/calorie intake [52]. In progressive NMDs, although many children may have learned to chew, masticatory problems may arise because of increasing weakness of the masseter and temporal muscles, in combination with weak tongue movements, resulting in prolonged mealtimes and the feeling that food is sticking in the throat.

\section{(b) The phase of dysfunctional swallowing}

\section{Problems in the oral preparatory and oral transport phases}

Oral muscle weakness influences the oral preparatory phase, resulting in weak sucking, weak mastication, or an inability to suck or chew. Weak sucking in the neonatal period often leads to (supplementary) tube feeding, which hampers the development of oral feeding [58]. Almost all NMDs of childhood are accompanied by mastication problems. The ability to chew depends on orofacial anatomical features, the coordination of these anatomical features, and the strength of the masticatory muscles [75]. In children with an NMD, the oral phase of swallowing is often complicated by structural impairments, such as malocclusions, limited mouth opening, tented upper lip, high arched palate, atrophic or hypertrophic tongue, or sunken cheeks. Together with the reduced force of the masticatory muscles, these abnormalities hamper the ability to chew solid food. Both human and animal studies have shown that food consistency affects orofacial development, suggesting that a diet with harder textures enhances bone and muscle growth [75]. If children with an NMD cannot handle chewable consistencies, then oral structures may not develop normally, which contributes to less efficient chewing.

Drooling of saliva and food is often due to poor lip seal, but it does not occur in all NMDs. Drooling in cerebral palsy has been extensively studied and is considered multifactorial with diminished subconscious swallowing frequency, insufficient oral suction, incomplete oral closure, tongue protrusion, slow tongue movements, and oral dyskinesia [76]. Drooling in NMDs is found mainly in children with severe bulbar weakness, such as congenital myotonic dystrophy, congenital myopathy, and Pompe disease. This suggests that drooling in these children is mainly due to oral weakness, such that there is reduced oral lip seal and limited oral suction of the tongue.

The main problems in the oral transport phase are piecemeal deglutition (the need for multiple swallows to clear the oral cavity), poor bolus formation, and oral residue after swallow. Many of these problems are caused by tongue weakness, so that affected children need more time to finish their meals.

\section{Problems in the pharyngeal phase}

Pharyngeal phase problems can range from nasal regurgitation, residue after swallow in the valleculae, piriform sinuses, and pharyngeal wall, to laryngeal penetration of food above the vocal folds and aspiration. Nasal regurgitation of food or liquid is caused by insufficient velopharyngeal closure but occurs in only a few NMDs, which underlines the different involvement of oral muscles in the various NMDs.

During a VFSS, solid food typically gives rise to more problems than does thin liquid [5, 22, 35, 42, 47]. In some cases, there is delayed initiation of swallowing, which suggests central nervous system involvement. Post-swallow residue and aspiration in combination with weak coughing and restrictive pulmonary function can lead to chest infections [52, 77], which is important to consider in children with NMD, presenting with pneumonia.

Reduced pharyngeal pressure during swallowing and insufficient opening of the upper esophageal sphincter, often because of weakness of the submental muscle group, hampers transport through the sphincter. This leads to post-swallow residue, potentially leading to indirect aspiration [77].

\section{Problems in the (upper) esophageal phase}

Post-swallow residue above the upper esophageal sphincter (which can be a pharyngeal or esophageal problem), esophageal dysmotility, and gastroesophageal reflux (GER) are common problems. Esophageal motor disorders are caused by weakness of the esophageal musculature [78], which might lead to ineffective peristalsis with retention of material in the esophagus after swallowing. In turn, the presence of residue can lead to regurgitation of material from the esophagus back into the pharynx, with the risk of aspiration of the regurgitated material [79]. As a result of neuromuscular incoordination and weakness, the antireflux function of the lower esophageal sphincter is reduced, which together with esophageal dysmotility leads to GER [78].

\section{(c) Disease progression}

Children with a nonprogressive NMD (such as some forms of congenital myopathy) often do not gain experience with feeding in the neonatal period. Oral feeding has to be introduced step by step, taking into account possible pharyngeal dysphagia [80]. Careful 
introduction of small amounts of liquid and food is important to monitor the safety of swallowing and to observe the development of oral skills. In our clinical experience, these children often receive their nutrition by means of oral and tube feeding [81].

Some NMDs are slowly progressive and, as a consequence, feeding and swallowing problems develop insidiously, which necessitates close professional monitoring from an early stage. Moreover, the involvement of oral muscles in different progressive NMDs is disease specific, resulting in different signs and symptoms of dysphagia. For example, patients with Duchenne muscular dystrophy, spinal muscular atrophy II/III, or childhood-onset myotonic dystrophy will not experience problems in the neonatal period, but may gradually develop chewing problems or choking, even in early stages of their disease.

\section{(d) Bulbar muscle involvement}

From Table 3 it is clear that the oral and pharyngeal muscles involved in feeding and swallowing are affected differently in the different NMDs. In some diseases the perioral and masticatory muscles are weak, which may affect facial growth and jaw mobility and may cause malocclusion. Masticatory muscle involvement will lead to chewing problems or, in some NMDs, to reduced mouth opening. Tongue weakness hampers adequate transport of food from the oral cavity to the pharyngeal area. Palatal involvement induces nasal regurgitation during swallowing. Involvement of the submental muscles and pharyngeal muscles leads to weak swallowing and to pharyngeal residue after swallowing. In addition, the oral muscles are not affected equally or at the same time in progressive NMDs [41]. Changes in the fine coordination of the activity of various oral muscles will adversely affect mastication, food transport, and swallowing.

\section{RECOMMENDATIONS}

On the basis of current knowledge and our clinical experience (expert opinion), we can formulate recommendations for the evaluation and management of dysphagia in children with NMDs.

\section{Comprehensive swallowing assessment}

The wide variety of signs and symptoms of dysphagia in NMD underlines the importance of a comprehensive feeding and swallowing assessment by a speech and language therapist (SLT) in infants and children with NMD presenting with dysphagia. Infants and children with an NMD show a wide range of intellectual abilities, and many children with intellectual impairment have feeding and swallowing problems as a result of the complex interactions between anatomical, medical, physiological, and behavioral factors [74]. These factors have to be taken into account during the assessment.

The underlying mechanisms of dysphagia have to be investigated carefully, focusing on the affected muscles and disturbances of the biomechanical events of swallowing. Oral muscle involvement can be monitored by muscle ultrasound, a promising and non-invasive tool, because muscle abnormalities may explain the biomechanical problems $[82,83]$. Investigation with VSSS or FEES is advised if there is concern about safe swallowing. Essential differences between children with central and peripheral neurologic disorders need to be taken into account.

\section{Use of a structured questionnaire}

Children with a slowly progressive NMD rarely spontaneously complain about chewing problems or the feeling that food is sticking in their throat, because they may adapt their feeding and swallowing habits to their reduced oral strength without realizing that they are doing so. This phenomenon has also been reported in adults with a progressive neuromuscular disorder [84]. It will lead to compensatory actions (either adequate or inadequate) with possible positive or adverse side effects [85]. Furthermore, patients and their parents are not always aware of the risks of dysphagia and possible solutions for the problem. They should be asked about mealtime duration (participation level) and the problems experienced (activity level). Chen et al. (2012) provided a semi-structured questionnaire including specific questions on feeding and swallowing ability, time needed to complete a meal, current motor function status, and current respiratory status [22]. They also paid attention to changing feeding and swallowing habits. Use of a structured questionnaire may unravel these changes, since sometimes individuals may subconsciously choose food consistencies that are easier to eat, which may mask dysphagia even in the early stages of an NMD [39, 41].

\section{Thickening liquids}

The primary aim in the rehabilitation of feeding and swallowing disorders is to achieve safety, i.e., to prevent choking and aspiration pneumonia. In many, but 
not all (e.g., spinal muscular atrophy I and hereditary sensory and autonomic neuropathy types 1 and II [22, 26, 27]) NMDs, children find it more difficult to cope with thick liquid and solid food than with thin liquids. In contrast to children with cerebral palsy, children with an NMD may experience more problems with post-swallow residue when drinking thickened liquids. The consistency of food/drink can best be determined on the basis of the results of a swallow study. Disease-specific recommendations are important, such as clearing pharyngeal residue by drinking water during and after meals. Furthermore, regular reassessment is necessary to evaluate disease progression or regression and the effects of interventions. Silent, sometimes life-threatening, aspiration can occur as a result of a weak cough and post-swallow residue. We recommend that airstacking or other lung volume recruiting therapies should not be used directly after a meal because of the risk of inhalation of pharyngeal residue. In the case of recurrent (aspiration) pneumonia, prophylactic antibiotic therapy should be considered in combination with non-oral feeding.

\section{Food adaptation}

Mastication problems are often reported as a result of weakness of the masticatory muscles and aberrations in masticatory performance, together with compromised dentition. In the case of mastication problems, softer foods and smaller pieces of food are recommended. These dietary changes should be monitored carefully, and patients should be seen by a dietician, to ensure that they have an adequate intake of nutrients, such as iron and fiber [86].

\section{Training}

The multifactorial feeding problems call for intensive collaboration between pediatric neurologist, SLT, rehabilitation physician, special dentist, and dietician, preferably in a multidisciplinary team. There is evidence that training is beneficial. For example, adaptation of the head posture of children with spinal muscular atrophy type II improves the efficiency of swallowing [5]. Beside adapting the consistency and portion size of food, task-specific training should be considered. Rehabilitation programs have shown taskrelated training [87] and swallowing training [88] to be effective in adults. Moreover, studies of motor function in children with neuromuscular disorders, such as Duchenne muscular dystrophy, have shown that 'no use is disuse' [89]. For example, confinement to a wheelchair was found to accelerate the loss of arm function of boys with Duchenne muscular dystrophy. Jansen et al. (2013) showed that assisted bicycle training of the legs and arms might slow the deterioration due to disuse [89]. Also a pilot study of boys and young adults with Duchenne muscular dystrophy showed that use of sugar-free chewing gum improved mastication [90]. These promising outcomes have to be studied over a longer period and in other groups of NMD.

\section{Tube feeding}

In the case of sucking and swallowing problems in the neonatal period, a nasogastric tube is used for feeding, to supplement the diet if the oral calorie intake is insufficient. If the sucking and swallowing difficulties persist for longer, it is often decided to place a gastrostomy. Gastrostomy placement may improve clinical outcomes and quality of life in children with progressive NMDs, who develop feeding and swallowing disorders later [81]. In a cohort of 36 children with NMD who underwent gastrostomy placement, 26 had a reduced frequency of chest infections [91]. However, no international guidelines are yet available for the indications for, and timing of, gastrostomy placement. DiVito and Meyers recommended that a feeding tube be placed if (a) the child aspirates on the VFSS, (b) mealtimes are always longer than 30 minutes, (c) the child is unable to meet nutritional needs for growth and development, (d) there is weight loss or lack of weight gain for 3 months, or (e) there is a decrease of 2 or more weight or height percentiles [92].

\section{Drooling treatment}

Drooling of saliva is reported in some NMDs, but especially in myotonic dystrophy, congenital myopathy, and Pompe disease. While the evaluation and treatment of drooling in children with cerebral palsy have been extensively studied [93], there is relatively little information about drooling in children with NMDs. Lip strengthening training in children with myotonic dystrophy was found to increase lip force and lip force endurance, but did not influence drooling [94]. Results from future studies on saliva control in NMDs have to be awaited.

\section{Malocclusion treatment}

Malocclusion in combination with oral muscle weakness, especially of the masseter muscles, may lead to open mouth posture and mastication problems. 
Various types of malocclusion occur in the various NMDs. For example, myotonic dystrophy is often accompanied by anterior open bite and posterior crossbite, with a large overjet (class II malocclusion), and distal occlusion [95]. In contrast, in Duchenne muscular dystrophy, anterior and posterior open bite and anterior crossbite (class III malocclusion) are reported [95]. There is a lack of clear information about the short- and long-term results of orthodontic treatment for malocclusion in NMD. For the time being, malocclusion problems require intensive collaboration between specialized dentists and specialists in feeding and swallowing problems in NMD. At the current time, we cannot make any recommendations, and studies about this topic are urgently needed.

\section{CONCLUSIONS}

The differences in the pathophysiology of feeding and swallowing problems necessitate disease-specific recommendations. In turn, this emphasizes the necessity of studying the neurophysiologic mechanisms of dysphagia in different types of childhood NMD. International guidelines for the treatment of children with NMDs, such as spinal muscular atrophy or congenital myasthenic syndrome, should be adapted in the light of available information. This will lead to tailored recommendations for children with feeding and swallowing disorders as a result of an NMD.

\section{CONFLICT OF INTEREST STATEMENT}

The authors have no conflict of interest to report.

\section{REFERENCES}

[1] Arvedson JC, Clark H, Lazarus C, Schooling T, Frymark T. Evidence-based systematic review: Effects of oral motor interventions on feeding and swallowing in preterm infants. Am J Speech Lang Pathol. 2010;19(4):321-40. doi: 10.1044/10580360

[2] Tilton AH, Miller MD, Khoshoo V. Nutrition and swallowing in pediatric neuromuscular patients. Semin Pediatr Neurol. 1998;5(2):106-15.

[3] Arvedson JC. Feeding children with cerebral palsy and swallowing difficulties. Eur J Clin Nutr. 2013;67(Suppl 2):S9-12. doi: 10.1038/ejen.2013.224

[4] van den Engel-Hoek L, Erasmus CE, van Hulst KC, Arvedson JC, de Groot IJ, de Swart BJ. Children with central and peripheral neurologic disorders have distinguishable patterns of dysphagia on videofluoroscopic swallow study. J Child Neurol. 2014;29(5):646-53. doi: 10.1177/0883073813501871
[5] van den Engel-Hoek L, Erasmus CE, van Bruggen HW, de Swart BJ, Sie LT, Steenks MH, et al. Dysphagia in spinal muscular atrophy type II: More than a bulbar problem? Neurology. 2009;73(21):1787-91.

[6] Dubowitz V. Muscle disorders in Childhood. London: W.B. Saunders Company LTD; 2000.

[7] Yang ML, Finkel RS. Overview of paediatric neuromuscular disorders and related pulmonary issues: Diagnostic and therapeutic considerations. Paediatr Respir Rev. 2010;11(1):9-17. doi: 10.1016/j.prrv.2009.10.009

[8] Delaney AL, Arvedson JC. Development of swallowing and feeding: Prenatal through first year of life. Dev Disabil Res Rev. 2008;14(2):105-17.

[9] Arvedson JC. Assessment of pediatric dysphagia and feeding disorders: Clinical and instrumental approaches. Dev Disabil Res Rev. 2008;14(2):118-27.

[10] Kostanjsek N. Use of The International Classification of Functioning, Disability and Health (ICF) as a conceptual framework and common language for disability statistics and health information systems. BMC Public Health. 2011;11(Suppl 4):S3. doi: 10.1186/1471-2458-11-S4-S3

[11] Logemann JA. Dysphagia: Evaluation and treatment. Folia Phoniatr Logop. 1995;47(3):140-64.

[12] Weir K, McMahon S, Barry L, Masters IB, Chang AB. Clinical signs and symptoms of oropharyngeal aspiration and dysphagia in children. Eur Respir J. 2009;33(3):604-11.

[13] Lunn MR, Wang CH. Spinal muscular atrophy. Lancet. 2008; 371(9630):2120-33. doi: 10.1016/S0140-6736(08)60921-6

[14] Wang CH, Finkel RS, Bertini ES, Schroth M, Simonds A, Wong B, et al. Consensus statement for standard of care in spinal muscular atrophy. J Child Neurol. 2007;22(8):1027-49.

[15] Davis RH, Godshall BJ, Seffrood E, Marcus M, Lasalle BA, Wong B, et al. Nutritional Practices at a Glance: Spinal Muscular Atrophy Type I Nutrition Survey Findings. J Child Neurol. 2013;11(29):1467-1472. doi: 10.1177/0883073813503988

[16] Willig TN, Paulus J, Lacau Saint GJ, Beon C, Navarro J. Swallowing problems in neuromuscular disorders. Arch Phys Med Rehabil. 1994;75(11):1175-81.

[17] Granger MW, Buschang PH, Throckmorton GS, Iannaccone ST. Masticatory muscle function in patients with spinal muscular atrophy. Am.J.Orthod.Dentofacial Orthop. 1999;115(6):697-702.

[18] van Bruggen HW, van den Engel-Hoek L, van der Pol WL, de Wijer A, de Groot IJ, Steenks MH. Impaired mandibular function in spinal muscular atrophy type II: Need for early recognition. J Child Neurol. 2011;26(11):1392-6. doi: 10.1177/088 3073811407696

[19] Markowitz JA, Singh P, Darras BT. Spinal muscular atrophy: A clinical and research update. Pediatr Neurol. 2012;46(1):112. doi: 10.1016/j.pediatrneurol.2011.09.001

[20] Messina S, Pane M, Rose PD, Vasta I, Sorleti D, Aloysius A, et al. Feeding problems and malnutrition in spinal muscular atrophy type II. Neuromuscul Disord. 2008;18(5):389-93.

[21] de Groot IJM, de Witte LP. Physical complaints in ageing persons with spinal muscular atrophy. J Rehabil Med. 2005;37(4):258-62.

[22] Chen YS, Shih HH, Chen TH, Kuo CH, Jong YJ. Prevalence and risk factors for feeding and swallowing difficulties in spinal muscular atrophy types II and III. J Pediatr. 2012;160(3):447-51 e1. doi: 10.1016/j.jpeds.2011.08.016

[23] Wilmshurst JM, Ouvrier R. Hereditary peripheral neuropathies of childhood: An overview for clinicians. Neuromuscul Disord. 2011;21(11):763-75. doi: 10.1016/j.nmd. 2011.05.013 
[24] Chapon F, Latour P, Diraison P, Schaeffer S, Vandenberghe A. Axonal phenotype of Charcot-Marie-Tooth disease associated with a mutation in the myelin protein zero gene. J Neurol Neurosurg Psychiatry. 1999;66(6):779-82.

[25] Asthana AK, Lubel JS, Kohn GP. Novel association of achalasia with hereditary sensory and motor neuropathy with sensorineural deafness. Dis Esophagus. 2013. doi: 10.1111/ dote. 12111

[26] Axelrod FB. Hereditary sensory and autonomic neuropathies. Familial dysautonomia and other HSANs. Clin Auton Res. 2002;12 Suppl 1:I2-14.

[27] Axelrod FB, Hilz MJ. Inherited autonomic neuropathies. Semin Neurol. 2003;23(4):381-90. doi: 10.1055/s-2004-817 722

[28] Liew WK, Kang PB. Update on juvenile myasthenia gravis. Curr Opin Pediatr. 2013;25(6):694-700. doi: 10.1097/MOP.0b013e328365ad16

[29] VanderPluym J, Vajsar J, Jacob FD, Mah JK, Grenier D, Kolski H. Clinical characteristics of pediatric myasthenia: A surveillance study. Pediatrics. 2013;132(4):e939-44. doi: 10.1542/peds.2013-0814

[30] Palace J, Beeson D. The congenital myasthenic syndromes. J Neuroimmunol. 2008;201-202:2-5. doi: 10.1016/j.jneuroim. 2008.05.030

[31] Yeung WL, Lam CW, Fung LW, Hon KL, Ng PC. Severe congenital myasthenia gravis of the presynaptic type with choline acetyltransferase mutation in a Chinese infant with respiratory failure. Neonatology. 2009;95(2):183-6. doi: 10.1159/000155612

[32] Engel AG, Ohno K, Sine SM. Congenital myasthenic syndromes: Progress over the past decade. Muscle Nerve. 2003;27(1):4-25. doi: 10.1002/mus.10269

[33] Papazian O. Transient neonatal myasthenia gravis. J Child Neurol. 1992;7(2):135-41.

[34] Keesey JC. Clinical evaluation and management of myasthenia gravis. Muscle Nerve. 2004;29(4):484-505. doi: $10.1002 /$ mus. 20030

[35] T. Vaqar LZ, Edelman FS, Stafstrom CE. Juvenile Myasthenia gravis: Freqent presentation with Bulbar Symptoms. Journal of Pediatric Sciences. 2012;4(3):e142.

[36] Leung DG, Wagner KR. Therapeutic advances in muscular dystrophy. Ann Neurol. 2013;74(3):404-11. doi: 10.1002/ ana.23989

[37] Bushby K, Finkel R, Birnkrant DJ, Case LE, Clemens PR, Cripe L, et al. Diagnosis and management of Duchenne muscular dystrophy, part 1: Diagnosis, and pharmacological and psychosocial management. Lancet Neurol. 2010;9(1):77-93.

[38] van Bruggen HW, Van Den Engel-Hoek L, Steenks MH, Bronkhorst EM, Creugers NH, de Groot IJ, et al. Reduced mandibular range of motion in Duchenne Muscular Dystrophy: Predictive factors. J Oral Rehabil. 2015;42(6):430-438. doi: $10.1111 /$ joor. 12274

[39] Archer SK, Garrod R, Hart N, Miller S. Dysphagia in Duchenne muscular dystrophy assessed by validated questionnaire. Int J Lang Commun Disord. 2013;48(2):240-6. doi: 10.1111/j.1460-6984.2012.00197.x

[40] Botteron S, Verdebout CM, Jeannet PY, Kiliaridis S. Orofacial dysfunction in Duchenne muscular dystrophy. Arch Oral Biol. 2009;54(1):26-31. doi: 10.1016/j.archoralbio.2008.07. 012

[41] van den Engel-Hoek L, Erasmus CE, Hendriks JC, Geurts AC, Klein WM, Pillen S, et al. Oral muscles are progressively affected in Duchenne muscular dystrophy: Implications for dysphagia treatment. J Neurol. 2013;260(5):1295-303. doi: 10.1007/s00415-012-6793-y
[42] Aloysius A, Born P, Kinali M, Davis T, Pane M, Mercuri E. Swallowing difficulties in Duchenne muscular dystrophy: Indications for feeding assessment and outcome of videofluroscopic swallow studies. Eur J Paediatr Neurol. 2008; 12(3):239-45

[43] Jaffe KM, McDonald CM, Ingman E, Haas J. Symptoms of upper gastrointestinal dysfunction in Duchenne muscular dystrophy: Case-control study. Arch Phys Med Rehabil. 1990;71(10):742-4.

[44] Turner C, Hilton-Jones D. The myotonic dystrophies: Diagnosis and management. J Neurol Neurosurg Psychiatry. 2010;81(4):358-67.

[45] Rutherford MA, Heckmatt JZ, Dubowitz V. Congenital myotonic dystrophy: Respiratory function at birth determines survival. Arch Dis Child. 1989;64(2):191-5.

[46] Hageman AT, Gabreels FJ, Liem KD, Renkawek K, Boon JM. Congenital myotonic dystrophy; a report on thirteen cases and a review of the literature. J Neurol Sci. 1993;115(1):95-101.

[47] Sjogreen L, Engvall M, Ekstrom AB, Lohmander A, Kiliaridis $\mathrm{S}$, Tulinius $\mathrm{M}$. Orofacial dysfunction in children and adolescents with myotonic dystrophy. Dev Med Child Neurol. 2007;49(1):18-22.

[48] Echenne B, Rideau A, Roubertie A, Sebire G, Rivier F, Lemieux B. Myotonic dystrophy type I in childhood Long-term evolution in patients surviving the neonatal period. Eur $\mathrm{J}$ Paediatr Neurol. 2008;12(3):210-23. doi: 10.1016/j.ejpn.2007. 07.014

[49] Campbell C. Congenital Myotonic Dystrophy. J Neur Neurophys. 2012(S7):001. doi: 10.4172/2155-9562.S7-001

[50] North KN, Wang CH, Clarke N, Jungbluth H, Vainzof M, Dowling JJ, et al. Approach to the diagnosis of congenital myopathies. Neuromuscul Disord. 2014;24(2):97-116. doi: 10.1016/j.nmd.2013.11.003

[51] North KN, Laing NG, Wallgren-Pettersson C. Nemaline myopathy: Current concepts. The ENMC International Consortium and Nemaline Myopathy. J Med Genet. 1997;34(9): 705-13.

[52] Bagnall AK, Al-Muhaizea MA, Manzur AY. Feeding and speech difficulties in typical congenital Nemaline myopathy. Advances in Speech-Language Pathology. 2006 2006:7-16.

[53] van den Engel-Hoek L, Erasmus CE, de Swart BJ, Sie LT, de Groot IJ. Neonatal swallowing assessment and practical recommendations for oral feeding in a girl with a severe congenital myopathy. J Child Neurol. 2011;26(8):1041-4. doi: 10.1177/0883073811402071

[54] Ryan MM, Schnell C, Strickland CD, Shield LK, Morgan G, Iannaccone ST, et al. Nemaline myopathy: A clinical study of 143 cases. Ann Neurol. 2001;50(3):312-20.

[55] Jungbluth H, Sewry C, Brown SC, Manzur AY, Mercuri E, Bushby K, et al. Minicore myopathy in children: A clinical and histopathological study of 19 cases. Neuromuscul Disord. 2000;10(4-5):264-73.

[56] Jungbluth H, Sewry CA, Muntoni F. Core myopathies. Semin Pediatr Neurol. 2011;18(4):239-49. doi: 10.1016/j.spen.2011. 10.005

[57] Maggi L, Scoto M, Cirak S, Robb SA, Klein A, Lillis S, et al. Congenital myopathies-clinical features and frequency of individual subtypes diagnosed over a 5-year period in the United Kingdom. Neuromuscul Disord. 2013;23(3):195-205. doi: 10.1016/j.nmd.2013.01.004

[58] Wang CH, Dowling JJ, North K, Schroth MK, Sejersen T, Shapiro F, et al. Consensus statement on standard of care for congenital myopathies. J Child Neurol. 2012;27(3):363-82. doi: $10.1177 / 0883073812436605$ 
[59] Fan HC, Lee CM, Harn HJ, Cheng SN, Yuh YS. X-linked centronuclear myopathy. Am J Perinatol. 2003;20(4):173-9. doi: $10.1055 / \mathrm{s}-2003-40603$

[60] Clarke NF. Congenital fiber-type disproportion. Semin Pediatr Neurol. 2011;18(4):264-71. doi: 10.1016/j.spen.2011.10. 008

[61] Clarke NF, North KN. Congenital fiber type disproportion-30 years on. J Neuropathol Exp Neurol. 2003;62(10):977-89.

[62] Tobon A. Metabolic myopathies. Continuum (Minneap Minn). 2013;19(6 Muscle Disease):1571-97. doi: 10.1212/01. CON.0000440660.41675.06

[63] van Adel BA, Tarnopolsky MA. Metabolic myopathies: Update 2009. J Clin Neuromuscul Dis. 2009;10(3):97-121. doi: 10.1097/CND.0b013e3181903126

[64] Sofou K, De Coo IF, Isohanni P, Ostergaard E, Naess K, De Meirleir L, et al. A multicenter study on Leigh syndrome: Disease course and predictors of survival. Orphanet J Rare Dis. 2014;9(1):52. doi: 10.1186/1750-1172-9-52

[65] Kisler JE, Whittaker RG, McFarland R. Mitochondrial diseases in childhood: A clinical approach to investigation and management. Dev Med Child Neurol. 2010;52(5):422-33. doi: $10.1111 / \mathrm{j} .1469-8749.2009 .03605 . \mathrm{x}$

[66] Jones HN, Muller CW, Lin M, Banugaria SG, Case LE, Li JS, et al. Oropharyngeal Dysphagia in Infants and Children with Infantile Pompe Disease. Dysphagia. 2009;25:277-83.

[67] van Gelder CM, van Capelle CI, Ebbink BJ, Moor-van Nugteren I, van den Hout JM, Hakkesteegt MM, et al. Facial-muscle weakness, speech disorders and dysphagia are common in patients with classic infantile Pompe disease treated with enzyme therapy. J Inherit Metab Dis. 2012;35(3):505-11. doi: 10.1007/s10545-011-9404-7

[68] Kishnani PS, Steiner RD, Bali D, Berger K, Byrne BJ, Case $\mathrm{LE}$, et al. Pompe disease diagnosis and management guideline. Genet Med. 2006;8(5):267-88

[69] Mammen AL, Casciola-Rosen LA, Hall JC, ChristopherStine L, Corse AM, Rosen A. Expression of the dermatomyositis autoantigen Mi-2 in regenerating muscle. Arthritis Rheum. 2009;60(12):3784-93. doi: 10.1002/art.24977

[70] McCann LJ, Juggins AD, Maillard SM, Wedderburn LR, Davidson JE, Murray KJ, et al. The Juvenile Dermatomyositis National Registry and Repository (UK and Ireland)clinical characteristics of children recruited within the first 5 yr. Rheumatology (Oxford). 2006;45(10):1255-60. doi: 10.1093/rheumatology/kel099

[71] McCann LJ, Garay SM, Ryan MM, Harris R, Riley P, Pilkington CA. Oropharyngeal dysphagia in juvenile dermatomyositis (JDM): An evaluation of videofluoroscopy swallow study (VFSS) changes in relation to clinical symptoms and objective muscle scores. Rheumatology (Oxford). 2007;46(8):1363-6. doi: 10.1093/rheumatology/kem131

[72] Ravelli A, Trail L, Ferrari C, Ruperto N, Pistorio A, Pilkington $\mathrm{C}$, et al. Long-term outcome and prognostic factors of juvenile dermatomyositis: A multinational, multicenter study of 490 patients. Arthritis Care Res (Hoboken). 2010;62(1):63-72. doi: 10.1002/acr.20015

[73] Cichero JA, Steele C, Duivestein J, Clave P, Chen J, Kayashita $\mathrm{J}$, et al. The Need for International Terminology and Definitions for Texture-Modified Foods and Thickened Liquids Used in Dysphagia Management: Foundations of a Global Initiative. Curr Phys Med Rehabil Reports. 2013;1:280-91. doi: $10.1007 / \mathrm{s} 40141-013-0024-\mathrm{z}$

[74] Cooper-Brown L, Copeland S, Dailey S, Downey D, Petersen $\mathrm{MC}$, Stimson C, et al. Feeding and swallowing dysfunction in genetic syndromes. Dev Disabil Res Rev. 2008;14(2):147-57.
[75] Le Reverend BJ, Edelson LR, Loret C. Anatomical, functional, physiological and behavioural aspects of the development of mastication in early childhood. Br J Nutr. 2014;111(3):403-14. doi: 10.1017/S0007114513002699

[76] Erasmus CE, Hulst K van, Rotteveel LJ, Jongerius PH, van den Hoogen FJ, Roeleveld N, et al. Drooling in cerebral palsy: Hypersalivation or dysfunctional oral motor control? Dev Med Child Neurol. 2009;51(6):454-9.

[77] Weir KA, McMahon S, Taylor S, Chang AB. Oropharyngeal aspiration and silent aspiration in children. Chest. 2011;140(3):589-97.

[78] Sullivan PB. Gastrointestinal disorders in children with neurodevelopmental disabilities. Dev Disabil Res Rev. 2008;14(2):128-36.

[79] Matsuo K, Palmer JB. Anatomy and physiology of feeding and swallowing: Normal and abnormal. Phys Med Rehabi Clin N Am. 2008;19(4):691-707. doi: 10.1016/j.pmr.2008. 06.001

[80] van den Engel-Hoek L, Erasmus CE, de Swart BJ, Sie LT, de Groot IJM. Neonatal swallowing assessment and practical recommendations for oral feeding in a girl with a severe congenital myopathy. J Child Neurol. 2011;26(8):1041-4.

[81] Seguy D, Michaud L, Guimber D, Cuisset JM, Devos P, Turck $\mathrm{D}$, et al. Efficacy and tolerance of gastrostomy feeding in pediatric forms of neuromuscular diseases. J Parenter Enteral Nutr. 2002;26(5):298-304

[82] van den Engel-Hoek L, van Alfen N, de Swart BJ, de Groot IJM, Pillen S. Quantitative ultrasound of the tongue and submental muscles in children and young adults. Muscle Nerve. 2012;46(1):31-7.

[83] Jansen BH, Pillen S, Voet NB, Heerschap A, van Engelen BG, van Alfen N. Quantitative muscle ultrasound versus quantitative magnetic resonance imaging in facioscapulohumeral dystrophy. Muscle Nerve. 2014;50(6):968-75. doi: $10.1002 /$ mus. 24247

[84] de Swart BJ, van der Sluijs BM, Vos AM, Kalf JG, Knuijt S, Cruysberg JR, et al. Ptosis aggravates dysphagia in oculopharyngeal muscular dystrophy. J Neurol Neurosurg Psychiatry. 2006;77(2):266-8

[85] de Swart B. Speech therapy in patients with neuromuscular disorders and Parkinson's disease.: Radboud University Nijmegen, the Netherlands; 2006.

[86] van der Bilt A. Assessment of mastication with implications for oral rehabilitation: A review. J Oral Rehabil. 2011;38(10):754-80. doi: 10.1111/j.1365-2842.2010. 02197.x

[87] Ramdharry GM. Rehabilitation in practice: Management of lower motor neuron weakness. Clin Rehabil. 2010;24(5): 387-97

[88] Carnaby-Mann GD, Crary MA. McNeill dysphagia therapy program: A case-control study. Arch Phys Med Rehabil. 2010;91(5):743-9. doi: 10.1016/j.apmr.2010.01.013

[89] Jansen M, van Alfen N, Geurts AC, de Groot IJ. Assisted bicycle training delays functional deterioration in boys with Duchenne muscular dystrophy: The randomized controlled trial "no use is disuse". Neurorehabil Neural Repair. 2013;27(9):816-27. doi: 10.1177/1545968313496326

[90] Bruggen HW, Engel-Hoek LV, Steenks MH, Bilt AV, Bronkhorst EM, Creugers NH, et al. Fighting Against Disuse of the Masticatory System in Duchenne Muscular Dystrophy: A Pilot Study Using Chewing Gum. J Child Neurol. 2015;30(12):1625-32. doi: 10.1177/0883073815575575

[91] Ramelli GP, Aloysius A, King C, Davis T, Muntoni F. Gastrostomy placement in paediatric patients with neuromuscular 
disorders: Indications and outcome. Dev Med Child Neurol. 2007;49(5):367-71. doi: 10.1111/j.1469-8749.2007.00367.x

[92] DiVito DMT, Meyers, R. Nutrition assessment of children with neuromuscular disease at the Children's Hospital of Philadelphia. Top Clinical Nutrition. 2012;27(3):11. doi: 10.1097/TIN.0b013e318262930a

[93] Erasmus CE, van HK, Rotteveel JJ, Willemsen MA, Jongerius $\mathrm{PH}$. Clinical practice : Swallowing problems in cerebral palsy. Eur J Pediatr. 2012;171:409-14.
[94] Sjogreen L, Tulinius M, Kiliaridis S, Lohmander A. The effect of lip strengthening exercises in children and adolescents with myotonic dystrophy type 1 . Int J Pediatr Otorhinolaryngol. 2010;74(10):1126-34. doi: 10.1016/j.ijporl.2010.06.013

[95] Kiliaridis S, Katsaros C. The effects of myotonic dystrophy and Duchenne muscular dystrophy on the orofacial muscles and dentofacial morphology. Acta Odontol Scand. 1998;56(6):369-74. 